\title{
REgUlation A AND The JOBS ACT: A FAILURE TO RESUSCITATE
}

\author{
RUTHEFORD B CAMPBELL, JR.
}

\begin{abstract}
Regulation $A$ offers small businesses an exemption from the registration requirements of the Securities Act of 1933. The exemption is generally consistent with the obligation of the Securities and Exchange Commission to fashion exemptions that balance investor protection and capital formation. From the perspective of small businesses, the exemption may appear to provide an efficient access to external capital.

Regulation $A$, however, has fallen into nearly complete disuse. The millions of small businesses in this country, all of which at some point need external capital to survive and grow, simply do not use Regulation $A$.

Two reasons account for small businesses' non-use of Regulation A. First, the disclosure and filing requirements for Regulation $A$ are somewhat out of balance, unnecessarily increasing the relative offering costs. Second, and much more important, is the impact of the registration provisions of state securities laws. The added burden-and expense-of meeting the state registration requirements simply price Regulation $A$ out of the marketplace for exemptions.

Congress recently passed the Jumpstart Our Business Startups Act. Title IV of the JOBS Act delegates to the Commission broad authority to enact new regulations that cure the problems that made Regulation A unusable.

Unfortunately, it is unlikely that the Commission will step up to its responsibility to enact regulations that provide small businesses with efficient access to external capital. Historically, the Commission has shown an unwillingness to expand by regulation the preemption of state authority over the registration of securities. Without
\end{abstract}

\footnotetext{
* Rutheford B Campbell is the William L. Matthews, Jr. Professor of Law at the University of Kentucky College of Law in Lexington, KY, 40508. (859) 257-4050, rcampbel@uky.edu. The author thanks Brad Hart, Jesse Parrish and Aaron Moody for their assistance in the preparation of this article.
} 
preemption, the new regulatory regime under Title IV of the JOBS Act will be useless to small businesses in search of external capital.

Such an outcome would amount to an abdication of the Commission's responsibilities to enact regulations that balance investor protection and capital formation.

\section{THE THEORY OF AND NiCHE FOR REgulation A}

Section 5 of the Securities Act of $1933^{1}$ (the 1933 Act) requires companies selling their own securities to file a registration statement with the Securities and Exchange Commission (the SEC or the Commission) and disclose prescribed investment information to investors. Both the 1933 Act itself $^{2}$ and the SEC regulations enacted thereunder, ${ }^{3}$ however, offer issuers exemptions from the registration and prospectus delivery requirements.

The broad underlying philosophy for the generally available exemptions from the registration requirement is well captured by section 2(b) of the 1933 Act. $^{4}$ That provision applies to the Commission when it enacts exemptions from the registration requirement, and in that case it instructs the Commission to "consider, in addition to the protection of investors, whether the action will promote efficiency, competition, and capital formation.",

In our market economy such a balanced approach to society's rules respecting capital formation is essential. An efficient allocation of capital requires that investors be protected from fraud, misinformation and undisclosed material facts. At the same time, rules respecting capital formation must not be so burdensome that they unreasonably throttle the migration of capital to its highest and best use.

Regulation $\mathrm{A}^{6}$ was a rational implementation by the Commission of this philosophy of balance. It provides small businesses an exemption from

\footnotetext{
${ }^{1}$ Securities Act of $1933 \S 5,15$ U.S.C. $\S 77 \mathrm{e}$ (2006), amended by Jumpstart Our Business Startups Act, Pub. L. No. 112-106, $\S 105(c), 126$ Stat. 311 (2012) (to be codified in scattered sections of 15 U.S.C.).

${ }^{2}$ The so-called private placement exemption provides an exemption from the registration requirements of section 5 for "transactions by an issuer not involving any public offering." $I d$. $\S 77 \mathrm{~d}(\mathrm{a})(2)$.

${ }^{3}$ See 17 C.F.R. $\S \S 230.501-.508$ (2012) (providing exemptions from registrations for certain offerings that may roughly be described as small and/or private offerings).

${ }^{4} 15$ U.S.C. $\$ 77 \mathrm{~b}$.

${ }^{5} \mathrm{Id} . \S 77 \mathrm{~b}(\mathrm{~b})$.

${ }^{6}$ Acting pursuant to its delegated authority under section 3(b) of the Securities Act of 1933, the SEC enacted Regulation A, 17 C.F.R $\S \S 230.251-.263$.
} 
registration for offerings of up to five million dollars. ${ }^{7}$ The exemption is predicated on the issuer's filing and disclosure of closely tailored investment information. ${ }^{8}$

Thus, disclosure - the primary investor protection device of the 1933 Act-is a predicate to the exemption's availability, but disclosures are significantly and rationally limited. ${ }^{9}$ Mandated disclosure is designed to protect investors, while the limited amount and nature of the disclosure requirements is intended to prevent excessive regulatory costs from foreclosing small businesses from using the Regulation A exemption.

Not only is the Commission's Regulation A philosophically sound as a rational attempt to balance investor protection and capital formation, but also it provides-at least apparently-an attractive path for small businesses to use in accessing external capital. Indeed, Regulation A was for decades the only generally available exemption from registration that enabled issuers to make an interstate public offering of their securities. Stated otherwise, Regulation A was the only generally available exemption from registration that enabled small companies to engage in a broad, interstate search for investors. ${ }^{10}$

Regulation A, however, fell into nearly complete disuse. The millions of small businesses in this country, all of which at some point need external capital to survive and grow, simply did not use Regulation A.

In 2012, Congress passed the Jumpstart Our Business Startups Act ${ }^{11}$ (the JOBS Act). Title IV of the JOBS Act, which is entitled Small Business Capital Formation, directs the Commission to enact a new exemption regime that significantly expands the exemption presently provided by Regulation A. ${ }^{12}$

\footnotetext{
${ }^{7} 17$ C.F.R. $\$ 230.251$ (b) (" $\$ 5,000,000 \ldots$ less the aggregate offering price for all securities sold within the twelve months before the start of and during the offering of securities in reliance upon Regulation A.").

${ }^{8}$ The issuer is required to file an offering statement with the Commission, and provide investors with an offering circular. $I d$. $\S 230.251(\mathrm{~d})(2)(\mathrm{i})$; see Rutheford B Campbell, Jr., Regulation A: Small Businesses' Search for "A Moderate Capital," 31 DEL. J. CORP. L. 77, 104-06 (2006) (detailing descriptions of the information disclosure requirements of a Regulation A offering).

${ }^{9}$ Campbell, supra note 8, at 104-06.

${ }^{10}$ Regulation A also has a so-called "test the waters" provision, which permits issuers utilizing Regulation A to solicit broadly indications of interests from investors before filing an offering statement and providing investors with an offering circular. 17 C.F.R. $§ 230.254$.

${ }^{11}$ Jumpstart Our Business Startups Act, Pub. L. No. 112-106, 126 Stat. 306 (2012) (to be codified in scattered sections of 15 U.S.C.).

${ }^{12}$ Id. $\$ \S 401-02$.
} 
The purposes of this paper are the following: (a) to describe the reasons why the Commission's Regulation A utterly failed as a vehicle for small businesses to access external capital; and (b) to analyze the extent to which Title IV of the JOBS Act will remedy, or at least ameliorate, the Commission's Regulation A failure and thus offer small businesses a new regulatory exemption that allows an efficient access to external capital and provides society with a regulatory regime that properly balances investor protection and capital formation.

In Section II of this Article, I provide data demonstrating the non-use of Regulation A and offer an explanation for this unfortunate circumstance. In Section III of this Article, I explain Title IV of the JOBS Act and its impact on small businesses' search for external capital. The conclusions of my analysis are that it is unlikely that the JOBS Act will either reinvigorate Regulation A or enhance small businesses' access to external capital.

\section{Non-USE of REgulation A: DATA AND EXPLANATION}

Data available from the Small Business Administration (the SBA) show that there are more than five million small businesses in the United States with fewer than twenty employees. ${ }^{13}$ These small businesses are vital to our national economy, accounting for approximately $18 \%$ of our national employment. ${ }^{14}$ SBA data show that firms with less than 100 workers provide as much $36 \%$ of our national employment. ${ }^{15}$

Data show, however, that these millions of small businesses do not rely on Regulation A as a vehicle for access to external capital. Table I, below, provides data on the total and average annual numbers of Regulation $\mathrm{A}$ offerings during two recent periods of time. When compared to the millions of small businesses, Table I demonstrates that Regulation A was essentially unused by small businesses over the sixteen year period covered by Table I.

${ }^{13}$ See Small Bus. Admin., The Small Business Economy: A REPORT to the PRESIDENT 2010, at 121 (2010) [hereinafter THE SMALl Business ECONOMY 2010] (in 2007, firms with less than twenty employees employed 5,410,367 workers). ${ }^{14}$ See id. at 121 (in $2007,18.1 \%$ of all employment was provided by firms with less than twenty employees). Earlier SBA data showed a slightly higher percentage of employment provided by these smallest firms. E.g., SMALL BUS. ADMIN., THE STATE OF SMAll Business: A RePort OF THE PRESIDENT 1999-2000, at 61 (in $1998,18.8 \%$ of all employment was provided by firms with less than twenty employees).

${ }^{15}$ Small Bus. Admin., The Small Business Economy: A RePORT to THE PRESIDENT 2004, at 178 [hereinafter THE SMALL BUSINESS ECONOMY 2004]. 
Table I

\begin{tabular}{cll}
\hline Time Period & $\begin{array}{c}\text { Total Number of } \\
\text { Regulation A Offerings }\end{array}$ & $\begin{array}{c}\text { Average Annual Number } \\
\text { of Regulation A Offerings }\end{array}$ \\
\hline $1 / 1 / 95-12 / 31 / 04^{16}$ & 78 & 7.8 \\
\hline $1 / 1 / 05-1 / 1 / 11^{17}$ & 162 & 23.1 \\
\hline
\end{tabular}

The non-use of Regulation A cannot be explained by any lack of demand for external capital by small businesses. Various data sets, for example, show that $80 \%$ to $90 \%$ of small businesses rely on external debt as a way of financing their operations. ${ }^{18}$

Table II, below, also reflects the demand of small businesses for external capital. The Table is based on 27,234 Form Ds filed in connection with Regulation D offerings over a recent twenty-five month period. It shows the total number of all Regulation $\mathrm{D}$ offerings during the period that were one million dollars or less and that were between one million and five million dollars. Table II also shows the percentages of the total Regulation $\mathrm{D}$ offerings that were within those smaller ranges.

Table II $^{19}$

\begin{tabular}{lll}
\hline & $\begin{array}{c}\text { Regulation D Offerings } \\
\text { of \$1 Million or Less }\end{array}$ & $\begin{array}{c}\text { Regulation D Offerings of } \\
\text { \$1 Million to \$5 Million }\end{array}$ \\
\hline Number & $7880 / 27,234$ & $7059 / 27,234$ \\
Percentage & $28.9 \%$ & $25.9 \%$ \\
\hline
\end{tabular}

Table II indicates that over the twenty-five month period, a total of nearly 15,000 Regulation $D$ offerings were made in amounts of less than

\footnotetext{
${ }^{16}$ Campbell, supra note 8, at 83 (data taken from Historical SEC Edgar Archives, available at $\mathrm{http}: / /$ www.sec.gov/cgi-bin/srch-edgar?text=1-a\&first=1994\&last= $2004 \&$ mode $=$ Simple (last visited Oct. 30, 2012)).

${ }^{17}$ Regulation A data were obtained from the subscription-only Knowledge Mosaic website. See Form A Data, KNOwLEDGE MosAIC, www.knowledgemosaic.com (last visited Oct. 11, 2011) (follow "SEC Filings" hyperlink; then search "Form 1A").

${ }^{18}$ See Campbell, supra note 8 , at $86-88$.

${ }^{19}$ Rutheford B Campbell, Jr., The Wreck of Regulation D: The Unintended (and Bad) Outcomes for the SEC's Crown Jewel Exemptions, 66 Bus. LAW. 919, 927 (2011). Regulation D data were obtained from the subscription only Knowledge Mosaic website. The data are for Form D filings from September 15, 2008 to October 18, 2010. See Form D Data, KNOwLEDGE MOSAIC, www.knowledge mosaic.com (last visited Apr. 1, 2011) (follow "Form D" hyperlink; then search "Form D").
} 
five million dollars. ${ }^{20}$ This represents approximately $55 \%$ of all Regulation $\mathrm{D}$ offerings during the period.

The question remains: Why did the millions of small issuers in the United States, the vast majority of which needed external capital in order to survive and compete, essentially never use Regulation A, the only generally available exemption that permitted a wide, interstate search for capital?

In a prior article, I offered two explanations for this curious circumstance. $^{21}$ First, and by far the less important, is the fact that Regulation A probably needs some fine tuning by the Commission in order better to promote efficient small business capital formation. ${ }^{22}$ I opined in my prior article that the five million dollar limit on Regulation A was "more than adequate to meet the needs or capital raising abilities of most small issuers." ${ }^{23}$ I focused attention on small offerings, where relative transaction costs are most pernicious to access to external capital. ${ }^{24} \mathrm{My}$ article was supportive of the general way in which the Commission has limited the mandatory disclosures in a Regulation A offering-especially the financial disclosures-but offered suggestions regarding further adjustments in Regulation A disclosures in small Regulation A offerings. ${ }^{25}$ My article also suggested limiting bureaucratic oversight as a way of efficiently reducing offering costs of a Regulation A offering. ${ }^{26}$

In short, although my article offered suggestions for improving Regulation A, the suggestions were rather modest. Certainly my criticisms did not detract from my strong support for the fundamental theory of Regulation A, which is to allow a broad and low cost search for investors while imposing the investor protection provision-mandated, reasonable level of disclosure of investment information-prior to sale. It is a theory that is sound and consistent with the overall disclosure philosophy of the 1933 Act.

The other explanation offered in my article for the non-use of Regulation $\mathrm{A}$ is the impact of registration requirements imposed by state blue sky laws. ${ }^{27}$ This problem is by far the more significant. The increase in the relative offering costs generated by the obligations to comply with state

\footnotetext{
${ }^{20}$ Campbell, supra note 19 , at 927 (exact total is 14,939 Regulation D offerings of less than five million dollars).

${ }^{21}$ See Campbell, supra note 8, at 112-23.

${ }^{22} \mathrm{Id}$. at $112-19$.

${ }^{23}$ Id. at 102.

${ }^{24} \mathrm{Id}$. at 113 .

${ }^{25} \mathrm{Id}$. at $113-18$.

${ }^{26}$ Id. at 118 ("any Commission review of Regulation A offerings should be eliminated").

${ }^{27}$ Campbell, supra note 8, at 106-12, 119-21.
} 
registration provisions simply price Regulation A out of the marketplace for exemptions, and Table I, above, shows the results.

Small issuers need small amounts of external capital. The obligations to comply with multiple state registrations requirements drive the relative offering costs to intolerable levels. As a result, small businesses seeking external capital must either find other, less desirable avenues for external capital or, in the worst case, continue to operate without the benefit of external capital. ${ }^{28}$ The unique niche for Regulation $A$ is that it offers an exemption from federal registration requirements for small interstate public offerings. "Interstate," of course, is the problem. If a small issuer offers its securities in three states, it must comply with four sets of separate and independent rules respecting registration (three states' laws and federal law). If the small issuer offers its securities in all fifty states (think, for example, of posting an offer on the issuer's website or placing an ad in a "local" newspaper that may have a modest national distribution), the issuer must comply with fifty-one sets of entirely independent rules respecting registration.

Over the years, states have offered various paths to coordinate Regulation $\mathrm{A}$ offerings with state registration requirements, including exemptions from state regulation requirements ${ }^{29}$ and various state registration alternatives. ${ }^{30}$ None of these options, however, has been

28 "Relative" costs are the issuer's expenses necessary to meet the conditions for the exemptions compared to the total proceeds from the offering. It is relative, not absolute, costs that practically destroy the availability of an exemption from registration. For example, if costs of meeting the conditions for an exemption are $\$ 50,000$, an issuer would not be willing to use the exemption for a $\$ 100,000$ offering (relative costs equal $50 \%$ ) but clearly could use the exemption for a five million dollar offering (relative costs equal 1\%).

${ }^{29}$ Typically, the most apparent broadly available state exemption for a Regulation A offering is the state small offering exemption. See, e.g., UNIF. SEC. ACT § 402(b), 7C U.L.A. 220 (2002). The severe limitations of the small offering exemption regarding the permissible number of offerees or purchasers make that exemption unsuitable for coordination with a Regulation A offering. Id.

${ }^{30}$ Most apparent is the traditional state registration by qualification. See, e.g., KaN. STAT. ANN. § 17-12a304 (West Supp. 2012); KY. REV. STAT. ANN. § 292.370 (West 2002); ME. REV. STAT. ANN. tit. 32, 10404 (West 2002) (repealed 2005). A large majority of states have adopted the SCOR (Small Corporate Offering Registration) form for registering offerings up to one million dollars, including Regulation A offerings. Small Corporate Offerings Registration Form (Form U-7), NASAA Rep. (CCH) \5057, \5197 (Dec. 1999). Some States also permit registration through coordination with a Regulation A offering. E.g., KY. REV. STAT. ANN. § 292.360. Essentially, this method allows issuers relying on Regulation A to meet their state obligations by filing their Form 1-A with the state. Id. 
successful as a way for small businesses to meet state requirements in a Regulation A offering. ${ }^{31}$

Regulation $\mathrm{A}$ is one of the ironies of modern securities regulation. It is a sensible and a philosophically sound exemption that should provide millions of small businesses an efficient access to capital. But it has been essentially unused by small businesses. In the next section of this paper, I examine the way Title IV of the JOBS Act impacts Regulation A offerings and the extent to which it may-or may not-provide small businesses an efficient access to external capital.

\section{THE IMPACT OF THE JOBS ACT ON REGULATION A AND SMALl BusinesSES' ACCESS TO CAPITAL}

\section{A. Generally}

Title IV of the JOBS Act, which is entitled Small Company Capital Formation, amends section 3(b) of the 1933 Act by adding a new section 3(b)(2). ${ }^{32}$ That new statute requires the Commission to enact a new section 3(b) regulation providing an exemption from registration for offerings of up to fifty million dollars.

In order for the regulations enacted by the Commission under new section 3(b)(2) of the 1933 Act (section 3(b)(2) Regulations) to provide a rational and efficient access to capital for small businesses, two factors are critical. First, the costs of meeting the conditions for the exemption under the section 3(b)(2) Regulations must be reasonable in amount. If compliance with the new regulations generates unreasonable relative offering costs, small businesses simply will not be able to use the exemption.

Second, state authority over the registration of offerings under the section 3(b)(2) Regulations must be preempted. This, of course, is related to the first factor, since compliance with state registration requirements increases relative offering costs. Without complete preemption over offerings under the section 3(b)(2) Regulations, the regulatory costs of complying with state registration provisions will drive relative offering costs for small businesses to intolerable levels.

As a general matter, new section 3(b)(2) delegates to the Commission authority to deal with both of these matters. History suggests, however, that

${ }^{31}$ See Campbell, supra note 8, at 106-10 (explaining the reasons that made coordination with any of the registration options unsuitable for Regulation $\mathrm{A}$ offerings).

${ }^{32}$ Securities Act of $1933 \S 3($ b), 15 U.S.C. $\S 77$ c(b) (2006), amended by Jumpstart Our Business Startups Act, Pub. L. No. 112-106, $\S \S 401-02,126$ Stat. 306 (2012) (to be codified at 15 U.S.C. $\S 77 \mathrm{c}$ ). 
the Commission is unlikely exercise its delegated authority in a way that provides small businesses an efficient access to external capital under the section 3(b)(2) Regulations.

\section{B. Terms of New Section 3(b)(2)}

Although section $3(\mathrm{~b})(2)$ requires the Commission to enact a new regulatory exemption from registration, Congress generally delegated broad discretion to the Commission to prescribe the conditions for the exemption. It seems clear, however, that the purpose of the legislation is to cause the Commission to provide a new, larger regulatory exemption modeled on the regulatory exemption presently available under Regulation $\mathrm{A}$.

The most important of the mandatory provisions in section 3(b)(2) the provisions that Congress requires the Commission to impose as a condition for the exemption-are the aggregate offering limit of fifty million dollars in any twelve-month period ${ }^{33}$ and a requirement that the issuer "file audited financial statements with the commission annually.",34

The discretionary provisions that may be imposed by the Commission in section 3(b)(2) offerings are limited essentially only by "the public interest and ... the protection of investors." ${ }^{35}$ Section 2(b) of the $1933 \mathrm{Act}^{36}$ is important with regard to this "public interest" limitation. That section of the 1933 Act requires that the Commission, when enacting regulations in the "public interest," must also "consider, in addition to the protection of investors, whether the action will promote efficiency, competition and capital formation." ${ }^{37}$

Within this extremely broad delegation of authority, section 3(b)(2) suggests two requirements that the Commission may impose as a condition for the availability of the exemption. First, the Commission may predicate the availability of the exemption on an obligation on the part of the issuer to file with the Commission and disclose to investors investment

${ }^{33} 15$ U.S.C.A. $\S 77 \mathrm{c}(\mathrm{b})(2)(\mathrm{A})$ (West 2012) ("aggregate offering amount ... shall not exceed $\$ 50,000,000 ")$.

${ }^{34} \mathrm{Id}$.

${ }^{35}$ Other than the mandatory provisions described in notes 34 and 35 , supra, additional important provisions of the statute state that the "securities may be offered ... publicly," $i d . \S 77 \mathrm{c}(\mathrm{b})(2)(\mathrm{B})$, that the "securities shall not be restricted securities," $i d . \S 77 \mathrm{c}(\mathrm{b})(2)(\mathrm{C})$, that the express civil liabilities under section 12(a)(2), id. $\$ 77 l(2)$, shall apply, id. $\S 77 \mathrm{c}(\mathrm{b})(2)(\mathrm{C})$, that the Commission may allow solicitations of indications of interest prior to any filing with the Commission, id. $\S 77 \mathrm{c}(\mathrm{b})(2)(\mathrm{E})$, and, that the Commission may impose other conditions that it "may determine necessary in the public interest," $i d$.

$\S 77 \mathrm{c}(\mathrm{b})(2)(\mathrm{G})$.

${ }^{36} \mathrm{Id}$. $\S 77 \mathrm{~b}(\mathrm{~b})$.

${ }^{37}$ Id. 
information. $^{38}$ Second, the Commission may also impose periodic disclosure requirements on the issuer. ${ }^{39}$

This brief description shows that in section 3(b)(2) Congress obligates the Commission to enact an exemption regime that balances investor protection with capital formation. The language of section $3(\mathrm{~b})(2)$ also suggests that an integral part of the new section 3(b)(2) Regulations should be a requirement for disclosures of prescribed investment information to investors.

The most apparent way for the Commission to implement its obligations under section $3(\mathrm{~b})(2)$ is by constructing a regime of stepped disclosures that conditions the section 3(b)(2) exemption on modest disclosures for small offerings but requires an increase in the amount of disclosure as the size of the section $3(b)(2)$ transaction gets larger.

This is not, of course, new for the Commission. Regulation $\mathrm{D}^{40}$ is perhaps the most apparent example of this approach. As Regulation D transactions get larger in size, the exemptions of Regulation D generally require additional investor protection devices, specifically mandated disclosure and/or purchaser qualifications (accredited investor status or sophistication). ${ }^{41}$ Regulation $A$ is also an example of this stepped approached. In that exemption, the Commission scaled back disclosure requirements for the smaller Regulation A offerings compared to the disclosures required in registered offerings on Form S-1. ${ }^{42}$

${ }^{38} I d . \S 77 \mathrm{c}(\mathrm{b})(2)(\mathrm{G})$ ("conditions ... which may include ... (i) a requirement that the issuer ... file with the Commission and distribute to prospective investors an offering statement ....").

${ }^{39} 15$ U.S.C.A. $\$ 77 \mathrm{c}(\mathrm{b})(4)$ (West 2012) (may require issuer "to make available to investors and file with the Commission periodic disclosures ....”). As described above, see supra note 36 and accompanying textual discussion, a mandatory provision in section 3(b)(2) of the Securities Act of 1933 also requires the issuer to "file audited financial statements with the commission annually." 15 U.S.C.A. $\S 77 \mathrm{c}(\mathrm{b})(2)(\mathrm{F})$.

${ }_{40} 17$ C.F.R. $\S \S 230.501-.508$ (2012).

${ }^{41}$ Rule 504 of Regulation D provides and exemption from registration for offerings of up to one million dollars. Id. $\S 230.504$. The exemption is not predicated on disclosure or investor qualification (i.e. accredited investor status or sophistication). Rule 505 of Regulation D provides an exemption from registration for offerings of up to five million dollars. Id. $\S 230.505$. The exemption is generally predicated on the disclosure of prescribed investment information to investors but does not require investor qualification (i.e. accredited investor status or sophistication). Rule 506 of Regulation D provides and exemption from registration for offerings of unlimited size. $I d . \S 230.506$. The exemption is generally predicated both on disclosure of prescribed investment information and investor qualification (i.e. accredited investor status or sophistication). Id.

${ }^{42}$ See Campbell, supra note 8, at 104-06. 
Thus, it might make sense for the Commission to require, for example, very modest informational disclosure requirements ${ }^{43}$ for section $3(b)(2)$ offerings of one million dollars or less. For offerings of between one million and five million dollars, the Commission might model informational disclosure requirements roughly on the present iteration of Regulation A. Above five million dollars, relative offering costs come into balance, and the Commission could impose more burdensome disclosure obligations. $^{44}$

As stated above, the Commission is well prepared to construct a stepped disclosure regime for section 3(b)(2) offerings that appropriately balances investor protection and capital formation. Implementing such a strategy also involves the Commission in no apparent political matters or administrative turf wars.

The more difficult problem for the Commission-one that, unfortunately, does involve political matters and turf wars-will be dealing with the preemption of state authority over section $3(\mathrm{~b})(2)$ offerings. It is here where I fear the Commission by tepid action or, indeed, by inaction, will destroy any chance that section $3($ b)(2) has to become an effective and efficient vehicle for small business capital formation.

Title IV of the JOBS Act deals with preemption in the context of section $3(\mathrm{~b})(2)$ offerings by amending the National Securities Markets Improvement $\mathrm{Act}^{45}$ (NSMIA) to preempt state registration authority over section $3(\mathrm{~b})(2)$ offerings if the securities are "offered or sold on a national securities exchange" or if the securities are "offered or sold to a qualified purchaser, as defined by the Commission . . .."46 Since small businesses of the kind described in Section II of this article ${ }^{47}$ are not "offered or sold on a

\footnotetext{
${ }^{43}$ Although section 3(b)(2) empowers the Commission to predicate the section 3(b)(2) exemption of a filing and review requirement, it is difficult to sustain any argument in favor of such a requirement. The added costs of review and comment - both in terms of out of pocket and opportunity costs for the issuer and, also, in terms of the costs of delay-are difficult to justify by increases in economic efficiency from such a review. Generally, it would seem to make more'sense to rely on incentives generated by potential antifraud liabilities.

${ }^{44}$ Obviously, I am suggesting the same "steps" as the Commission used in Regulation D. 17 C.F.R. $§ \S 230.501-.508$; see discussion supra note 43.

${ }^{45}$ National Securities Markets Improvement Act of 1996, Pub. L. No. 104-290, 110 Stat. 3416 (codified in scattered sections of 15 U.S.C.). The Act preempted some state authority over the registration of securities. See 15 U.S.C. $\S 77$ r(a)-(b) (2006), amended by Jumpstart Our Business Startups Act, Pub. L. No. 112-106, § 401, 126 Stat. 306 (2012).

46 15 U.S.C.A. $\$ 77 \mathrm{r}(\mathrm{b})(4)(\mathrm{D})$.

${ }^{47}$ See supra notes $13-15$ and accompanying textual discussion.
} 
national securities exchange, ${ }^{, 48}$ preemption of state authority over section 3 (b)(2) offerings by small businesses depends on the investors in such offerings being "qualified purchasers," as that term is defined by the Commission.

The history of NSMIA is important with regard to the Commission's possible definitions of "qualified purchaser." As originally enacted, NSMIA preempted state authority over offers limited to "qualified purchasers." Congress, however, refused to define "qualified purchaser" and, instead, delegated to the Commission authority to define that critical term. ${ }^{49}$

This delegation of authority to define the term "qualified purchasers" was broad. ${ }^{50}$ The only limitation in the statute was a requirement that the definition of "qualified purchaser" must be "consistent with the public interest and the protection of investors." ${ }^{, 51}$ As if to emphasize the breadth of the Commission's power, the statute stated that "the Commission may define the term 'qualified purchaser' differently with respect to different categories of securities ....."52

Since the enactment of NSMIA in 1996, however, the Commission has shown little interest in expanding preemption by defining the term "qualified purchaser." In 2001 the Commission did propose to define

\footnotetext{
${ }^{48}$ My assumption is that "offered and sold on a national exchange" means that the securities are listed for trading on the national exchange.

${ }^{49} 15$ U.S.C.A. $\S 77 \mathrm{r}(\mathrm{a})(1)(\mathrm{A})$ (preempting state authority over "covered securit[ies]"); id. $\S 77 \mathrm{r}(\mathrm{b})(3)$ ("A security is a covered security with respect to the offer and sale of the security to qualified purchasers, as defined by the Commission ....').

${ }^{50}$ Writing the year after the enactment of NSMIA, I analyzed the breadth of the Commission's delegated authority to define "qualified purchaser." Rutheford B Campbell, Jr. Blue Sky Laws and the Recent Congressional Preemption Failure, 22 J. CORP. L. 175, 207-10 (1997). My conclusion, after exploring the political and legislative history of NSMIA and analyzing closely the language of the statue, was stated as follows:

The plain words of the Act give the Commission ample authority to enhance significantly the preemption under the Act. Congress has laid in the Commission's lap, finally, the means to eliminate state hegemony over capital formation and much of the nonsense of state blue sky laws and to provide badly needed and long overdue relief to small entrepreneurs.

Id. at 210.

${ }^{51} 15$ U.S.C.A. $\$ 77 \mathrm{r}(\mathrm{b})(3)$. Section 2(b) of the 1933 Act also requires that when the Commission is making rules "in the public interest," the Commission must "consider, in addition to the protection of investors, whether the action will promote efficiency, competition, and capital formation." Id. $\S 77 \mathrm{~b}(\mathrm{~b})$.

${ }^{52}$ Id. $\S 77 \mathrm{r}(\mathrm{b})(3)$.
} 
"qualified purchaser" as "any accredited investor" under Regulation $\mathrm{D}^{53}$ but the Commission failed to adopt that proposed amendment to NSMIA. Otherwise, the Commission has done essentially nothing regarding any significant definition of "qualified purchaser."

Faced now, as it is, with the obligation to enact regulations to implement new section 3(b)(2), various options are possible regarding a Commission definition of "qualified purchaser" and the extent of preemption of state authority over section 3(b)(2) offerings.

One option for the Commission is to follow its historic practice ${ }^{54}$ and refuse to enact any definition of "qualified purchaser." While the JOBS Act requires the Commission to enact a regulatory regime under section 3(b)(2), the JOBS Act contains no explicit mandate for the Commission to define "qualified purchaser" as a part of its regulatory implementation of the Act.

A Commission failure to define the term, however, would seem an abdication of its responsibilities, since it would destroy the availability of section 3(b)(2) for small issuers. As noted above, small businesses are not traded on national exchanges, and thus preemption over section $3(b)(2)$ offerings by small businesses can come only if a small business utilizing section 3(b)(2) limits its investors to "qualified purchasers." With no definition of that term, small businesses would be unable to attain preemption and, accordingly, be effectively foreclosed from use of new section 3(b)(2).

A second option for the Commission is to define a "qualified purchaser" as an "accredited investor" within the meaning of Regulation $\mathrm{D}^{55}$ This second option also essentially kills section $3(\mathrm{~b})(2)$ for small business capital formation. Defining "qualified purchaser" as an "accredited investor" severely limits the investor pool. Less than $5 \%$ of the population may meet that definition of "accredited investor." 56 Obviously, excluding such a huge majority of the population from potential investors in a section 3(b)(2) offering by small businesses takes away any advantages that small businesses may gain by relying on the exemption. Small businesses operating under such a regime cannot solicit broadly for investors.

What certainly will be the consequences of such a definition (whether intended or unintended) will be to move small business capital formation

\footnotetext{
${ }^{53}$ Defining the Term "Qualified Purchasers" Under the Securities Act of 1933, Securities Act Release No. 8041, 66 Fed. Reg. 66,839 (Dec. 27, 2001).

${ }^{54}$ Id.; see infra notes 62-64 and accompanying text.

${ }^{55}$ This option was proposed by the Commission in 2001, but it was never adopted. See Defining the Term "Qualified Purchasers" Under the Securities Act of 1933, supra note 53.

${ }^{56}$ Internal Revenue Service data from 2007 show that only $3.172 \%$ of all tax returns reported income of $\$ 200,000$ or more. Justin Bryan, High-Income Tax
} Returns for 2007, STAT. InCOME BULl. (Internal Revenue Serv.), Spring 2010, at 4. 
away from any section 3(b)(2) exemption and into Rule 506 offerings. Once the Commission acts to implement Title II of the JOBS Act, ${ }^{57}$ small issuers using Rule 506 and limiting their purchasers to accredited investors will be able to solicit broadly for investors (i.e. use general advertising to find investors) and sell to an unlimited number of accredited investors. ${ }^{58}$ These Rule 506 offerings limited to accredited investors, however, generate no disclosure obligations as a condition for the availability of the Rule 506 exemption. ${ }^{59}$ It seems certain, however, that the conditions for the availability of the section 3(b)(2) exemption imposed by the Commission will require some measure of disclosure. It is difficult to see why, in such circumstances, small businesses in search of external capital would use section 3(b)(2) instead of Rule $506^{60}$

A third option for the Commission is to define "qualified purchaser" as anyone who purchases under the section 3(b)(2). This, certainly, is the most appropriate of the three options. ${ }^{61}$ Unfortunately, it is also the option least likely to be adopted by the Commission.

If the Commission were to define "qualified purchaser" in this fashion and combine this with a closely tailored, stepped approach to disclosure and periodic reporting requirements, section 3(b)(2) could become an important exemption for small businesses capital formation. It would enable small

${ }^{57}$ Jumpstart Our Business Startups Act, Pub. L. No. 112-106, § 201, 126 Stat. 306 (2012) (to be codified at 15 U.S.C. $\S 77 \mathrm{~d}$ ). Title II is entitled "Access to Capital for Job Creators."

${ }^{58}$ On August 29, 2012, the Commission promulgated its proposed regulatory implementation of Congress's mandate regarding Rule 506, The Commission's proposal permits general solicitations and general advertisings in Rule 506 offerings. Such broadly advertised Rule 506 offerings can be sold only to "accredited investors." Eliminating the Prohibition Against General Solicitation and General Advertising in Rule 506 and Rule 144A Offerings, Securities Act Release No. 9354, 77 Fed. Reg. 54,464 (Sept. 5, 2012).

${ }^{59}$ There are no disclosure requirements for an offering under Rule 506 that is limited to accredited investors. 17 C.F.R. $\S \S 230.506$ (2012), 230.502(b)(1).

${ }^{60}$ One advantage of using section $3(\mathrm{~b})(2)$ is that investors could resell their section 3(b)(2) securities immediately. 15 U.S.C.A. $\S 77 \mathrm{c}(\mathrm{b})(2)$ (c) (West 2012) ("securities shall not be restricted securities"). Rule 506 securities are restricted. 17 C.F.R. $\S 230.502$ (d) (2012) (securities acquired under Rule 506 have the same status as "securities acquired ... under section 4(2)"). This means that investors would be required to hold the securities for six or twelve months before resale under Rule 144 or privately. 17 C.F.R. $\S 230.144$. Such a short holding period with the option to sell privately may not amount to a material impediment to capital formation in the case of most small companies.

${ }^{61}$ A better definition would be for the Commission to define a "qualified purchaser" as anyone purchasing under a section 3(b) exemption. For a discussion of this, see Campbell, supra note 50, at 207-10 (describing the policy justifications and the statutory and legislative history justifications for the Commission's exercise of broad preemption under NSMIA). 
businesses to solicit broadly for external capital without any investor qualification requirements (e.g., sophistication or accredited investor requirements), limitations on the number of offerees or purchasers ${ }^{62}$ or restrictions on the resale of securities. Perhaps most important, such a regime would permit a broad solicitation for investors without the necessity of complying with the daunting - and expensive-task of meeting the registration requirements of multiple state registration regimes.

Investors, for their part, would be protected by mandated disclosure of prescribed investment information, which is consistent with the disclosure philosophy that is the very core of the 1933 Act. The Commission with its vast experience, expertise and resources could construct these disclosure requirements under the obligation to balance investor protection and capital formation.

This option, however, is unlikely because it would amount to an expansion of preemption of state authority over registration, and the Commission has a history of unwillingness to push the preemption issue and thus encounter the predictable enmity of state regulators. In the enactment of NSMIA and the Dodd Frank Wall Street Reform and Consumer Protection Act of $2010^{63}$ (Dodd-Frank), for example, the Commission refused to advocate in favor of preemption, even though it was apparent that state regulation was destroying the availability of efficient federal exemptions from the registration requirements of the 1933 Act. State regulators, however, have robustly fought preemption through advocacy and the use of other legislative strategies. ${ }^{64}$

\footnotetext{
${ }^{62}$ It seems highly likely that the Commission in its section 3(b)(2) Regulations will permit small issuers to continue to "test the waters," similar to the present regulations governing Regulation A offerings. See 15 U.S.C.A. \& 77c(b)(2)(E) (the Commission may allow solicitations of indications of interest prior to any filing with the Commission).

${ }^{63}$ Dodd-Frank Wall Street Reform and Consumer Protection Act of 2010, Pub. L. No. 111-203, 124 Stat. 1376 (2010) (codified in scattered sections of 7, 12, 15, 18, 22 and 42 U.S.C.).

${ }^{64}$ See Campbell, supra note 19 , at $936-40$. With regard to the enactment of NSMIA, "the North American Securities Administrators Association (NASAA) .. . offered strong opposition to the legislation." Id. at 937. On the other hand, Arthur Levitt, who was then Chairman of the Commission, in his testimony and prepared remarks during the legislative hearings "skillfully dodged any support for broad preemption of state authority over securities offerings." Id. When Senator Christopher Dodd circulated a discussion draft of the bill that "would later become the core of the Dodd-Frank Wall Street Reform and Consumer Protection Act," the discussion draft contained a provision that "would have eliminated preemption of state authority over Rule 506 offerings." Id. at 938 (citations omitted). It was apparent that state regulators, acting through NASAA, were the architects of this strategy. See, e.g., Letter from Scott Edward Walker to Senator Christopher J.
} 
While one may understand the reluctance of the Commission to get itself crosswise with its fellow regulators, the Commission's inaction has essentially permitted states to wreck Regulation A, which should have been a very attractive path for small business capital formation. This, I suggest, is unfortunate for small business and the economy and amounts to an abdication of the Commission's express responsibilities under section 2(b) of the $1933 \mathrm{Act}^{65}$ to balance investor protection and capital formation.

My fear, therefore, is that the Commission will adopt some version of option one or two, above, essentially foreclosing small businesses from using the new section 3 (b)(2) exemption provided by Title IV of the JOBS Act, which-ironically-is entitled "Small Company Capital Formation."

\section{CONCLUSION}

Title IV of the JOBS Act delegates to the Commission the authority to enact new regulations that provide small businesses with an efficient access to capital and cure the problems that have made Regulation A unusable.

For this to happen, however, the Commission's regulations under the JOBS Act must be based on a stepped disclosure regime that requires companies to provide investors with increasing levels of investment information as the size of offerings increase. Even more important, the Commission also must exercise its delegated authority to preempt state registration authority over section $3(b)(2)$ offerings by small businesses.

Dodd (Mar. 31, 2010); Bill Carleton \& Joe Wallin, Dodd's Attack on Angel Financing, PUGET SOUND BUS. J. (Mar. 15, 2010, 1:15 PM), http://techflash.com/ seattle/2010/03/congress_attack_on_angel_financing.html; Broc Romanek, Dodd Bill Peculiarities: The SEC's Ré D Preemption Gets Hammered, THECORPORATECOUNSEL.NET (Mar. 23, 2010, 9:09 AM), http://www.thecorporate counsel.net/Blog/2010/03/an-office-of-investor-advocate.html. Again, as in the legislative hearings leading to the adoption of NSMIA, the Commission offered no meaningful support for the preservation of preemption for Rule 506 offerings. See Campbell, supra note 19, at 939. In 2001, the Commission offered a proposal to define "qualified purchaser" as an "accredited investor." Defining the Term "Qualified Purchasers" Under the Securities Act of 1933, supra note 53. The Commission failed to adopt the amendment. One explanation for the Commission's failure was objections from state regulators, who resisted any loss of state authority over registration. NASAA and States Oppose Proposed Definition of Qualified Purchaser, 202-63 SEC TODAY 1-2 (Apr. 2, 2002) ("NASAA . . expressed concerns that the preemption will increase the risk of fraud. States frequently use violations of their registration provisions as the basis for stopping fraud, NASAA explained.").

${ }^{65} 15$ U.S.C.A. $\S 77 \mathrm{~b}(\mathrm{~b})$. 
The question is whether the Commission has the will to implement such an efficient regulatory regime under this new delegated authority. Unfortunately for small businesses-and the economy-history suggests that it does not. 
